\title{
The Sources of Regional Variation in the Severity of the Great Depression: Evidence from U.S. Manufacturing, 1919-1937
}

\section{JOSHUA L. ROSENBLOOM AND WILLIAM A. SUNDSTROM}

The impact of the Great Depression was milder in the South Atlantic states, more severe in the Mountain states, and surprisingly uniform across other regions of the country -despite large differences in industrial structure. Employing data on 20 manufacturing industries disaggregated by state, we analyze the relative contributions of industry mix and location to regional variations in economic performance. Industrial composition had a significant impact on employment growth, with regions that concentrated on durable goods or inputs to construction faring worse than others. Long-run trends also mattered, and explain much of the South Atlantic's more favorable performance.

$\mathrm{T}$ The Great Depression was a global crisis, but its severity varied both spatially and sectorally. Within the United States, the severity of the 1929 to 1933 contraction differed substantially across regions and cities. Although all regions suffered considerable employment losses, the contraction was relatively milder and shorter in the South Atlantic states and more severe and prolonged in the Rocky Mountain states. The severity of the contraction also varied dramatically across sectors of the economy, with employment falling most in such industries as construction and durables manufacturing, more modestly in the service sector and nondurables manufacturing.

The economic fates of regions and industries were clearly linked. Regional economies that were more dependent on cyclically volatile industries were bound to suffer a relatively more severe contraction of economic activity during the Depression. But there may also have been a local component to economic shocks or their propagation that affected all or most industries within a region. A wave of bank failures in a specific region, for example, was a disruption to the region's capital markets that could affect any industry that depended on local sources of capital.

The Journal of Economic History, Vol. 59, No. 3 (Sept. 1999). (C) The Economic History Association. All rights reserved. ISSN 0022-0507.

Joshua L. Rosenbloom is Associate Professor, Department of Economics, University of Kansas, Lawrence, KS 66045, and Research Associate at the National Bureau of Economic Research. William A. Sundstrom is Associate Professor, Department of Economics, Santa Clara University, Santa Clara, CA 95053.

The authors thank Carol Heim, Michael Kevane, John Wallis, Gavin Wright, two anonymous referees, and participants in sessions at the 1997 meetings of the Economic History Association and the National Bureau of Economic Research for many helpful comments on a previous version. Florencia Carbone, Michael Metz, and Nimrod Posner provided research assistance. Rosenbloom's research was partially funded by University of Kansas General Research Fund Allocations 3828-20-0038 and 3828-30-0038; Sundstrom acknowledges the financial support of the Leavey School of Business and Administration at Santa Clara University. 
In this article we explore the sources of regional variation in the severity and duration of the Depression in the U.S. manufacturing sector, using a panel data set of employment in 20 manufacturing industries drawn from the biennial Censuses of Manufactures, 1919 to 1937. Because the data are disaggregated by industry and state, we are able to distinguish the effects of industry composition and region-specific effects. Furthermore, by using data that span nearly two decades, we are able to distinguish the short-run impact of the 1929 to 1933 contraction from longer trends in the growth of regional economies and industrial sectors. Controlling for the effects of both region and industry represents the major advance of our article over previous disaggregated analyses of the Depression, which have tended to examine either regional variation (for example, studies by John Wallis and George Borts) or industry variation (studies by Michael Bernstein and Rick Szostak), but not both simultaneously. ${ }^{1}$

Our analysis confirms the importance of industry mix in the impact of the downturn on regional economies. Regional manufacturing sectors that were particularly dependent on demand for inputs by the construction industry were especially adversely affected by the contraction. The importance of lumber production in the Mountain and East South Central regions, for example, accounts for their relatively worse performance during the downturn. In the South Atlantic region, where the contraction was relatively less severe, industry composition played a less important role. Instead, the South Atlantic benefitted from greater regional trend growth in its manufacturing sector. Our results suggest generally that region-specific effects of the cycle were rather small.

The results have implications for some theories of the causes of the Depression, even though we do not directly test these theories. To the extent that region-specific shocks played a limited role in creating regional differences, the results cast some doubt on theories that would imply strong idiosyncratic regional effects. For example, disruptions to local capital markets caused by regionally concentrated waves of bank failures do not appear to have had large effects on regional manufacturing sectors; nor do New Deal wage restrictions that may have been more binding in low-wage regions.

\section{REGIONAL VARIATION IN THE SEVERITY OF THE DEPRESSION}

Regional differences in the depth and duration of the Great Depression have been documented for a variety of economic indicators. ${ }^{2}$ Unemployment

\footnotetext{
'Wallis, "Employment"; Borts, "Regional Cycles"; Bernstein, Great Depression; and Szostak, Technological Innovation. The importance of disaggregation in recent work on the Great Depression is stressed by Margo, "Employment"; and Calomiris, "Financial Factors."

${ }^{2}$ Research using modern data has also found that states vary considerably in the degree to which their economic fluctuations are linked to national cycles (Sherwood-Call, "Exploring the Relation-
} 
rates varied considerably across cities and states, for example, and bank failures were more prevalent in farm states. ${ }^{3}$ In an important article, Wallis has shown that employment in both manufacturing and nonmanufacturing declined less (in percentage terms) and recovered more rapidly in the South-particularly the South Atlantic-than elsewhere. ${ }^{4}$ While other regional differences are also revealed by the data, the North-South contrast is the most dramatic.

Regional variation in the 1929 to 1933 decline and subsequent recovery are illustrated in Figures 1 and 2, which show, respectively, employment and the total value of output in manufacturing by census division for the period from 1919 through 1939, normalized to 100 in $1929 . .^{5}$ In most regions the trough in employment was reached in 1933, with 1933 employment typically 30 to 40 percent below its 1929 level, and recovery remained incomplete as late as 1939. The most notable exception is the South Atlantic division, where employment declined less than 20 percent below its 1929 level. ${ }^{6}$ The South Atlantic was the only division in which 1939 employment had recovered to a level above where it stood in 1929. The only other region showing significantly anomalous behavior is the Mountain region, where as late as 1939 manufacturing employment remained at less than 80 percent of its 1929 level. The regional movements of total product value (Figure 2) are largely consistent with those for employment. ${ }^{7}$

Evidence on nonmanufacturing industries is less extensive, but the basic regional patterns seem to hold outside manufacturing as well. Table 1 , for example, presents an index of employment in retail trade, again relative to the 1929 value, based on published figures from the Census of Business (available for 1929, 1933, 1935, and 1939). Retail employment was less volatile than manufacturing employment, but the superior performance of

ships"). Blanchard and Katz ("Regional Evolutions") show that there are persistent differences in rates of employment growth across states, with shocks tending to have a permanent effect on the level of employment. Clark ("Business Cycle Fluctuations") decomposes innovations in employment growth into national, region-specific, and industry-specific shocks. Controlling for broadly defined industry groups, he finds that on average about 40 percent of the variance of cyclical innovations in regional employment growth are region-specific (not attributable to national or industry-specific innovations).

${ }^{3}$ On unemployment see U.S. Dept. of Commerce, Fiffeenth Census and Sixteenth Census; and Simon and Nardinelli, "Does Industry Diversity." On bank failures see Chandler, America's Greatest Depression; Friedman and Schwartz, Monetary History, Temin, Did Monetary Forces; and Wicker, Banking Panics.

${ }^{4}$ Wallis, "Employment." See also, Borts, "Regional Cycles."

${ }^{3}$ The data in Figures 1 and 2 are derived from the Biennial Census of Manufactures (U.S. Department of Commerce (various years)). Because of a shift in industrial coverage in 1935, the 1935 figures are the mean of two values; one consistent with the earlier years and one consistent with the later years. The difference between these levels was not large.

"In this article we use the terms "region" and "division" interchangeably, always referring to the U.S. Census's definitions of divisions.

${ }^{7}$ Unemployment rates cannot be directly estimated at the state or regional level except in the decennial census years, 1930 and 1940 . For these years unemployment rates by geographical division parallel the differences in manufacturing employment. 

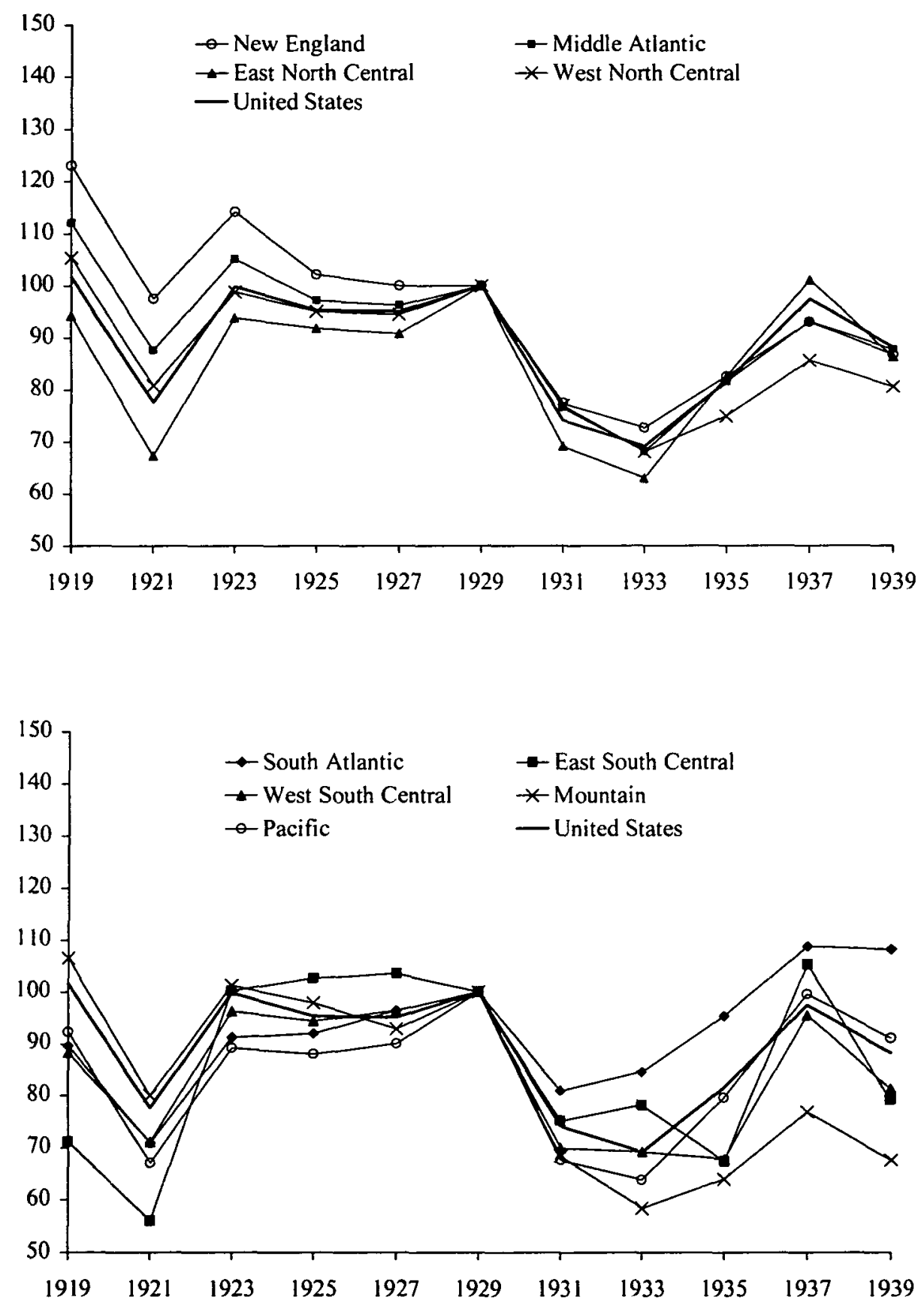

FIGURE 1

INDEX OF MANUFACTURING EMPLOYMENT $(1929=100)$

Note: Industrial coverage changed in 1935 . Figures for 1935 are the average of two values: one consistent with the industries covered in earlier years, the other consistent with later years.

Source: U.S. Department of Commerce, Census of Manufactures (various years). 

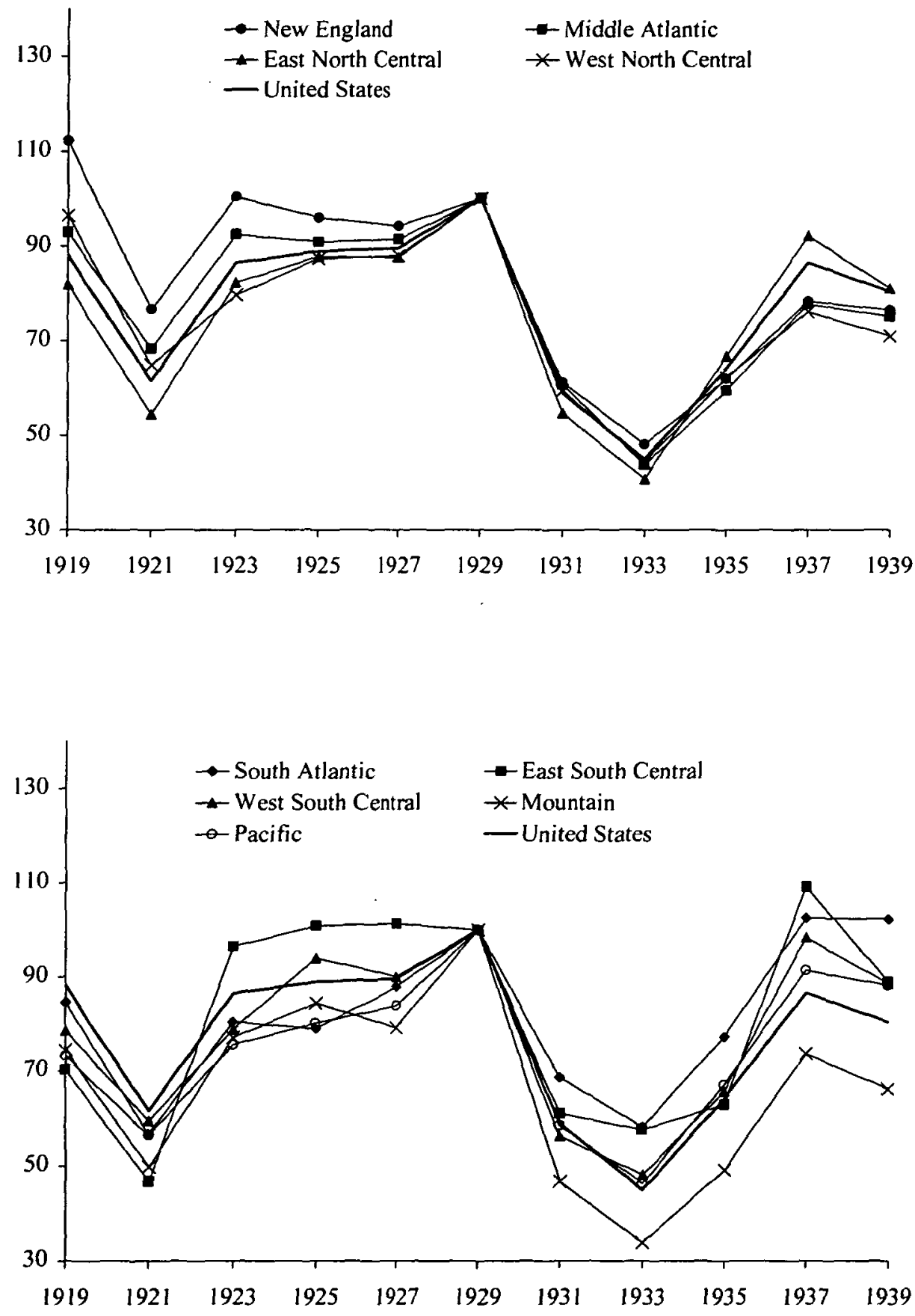

FIGURE 2

INDEX OF PRODUCT VALUES $(1929=100)$

Note: See Figure 1.

Source: See Figure 1. 
TABLE 1

INDEX OF RETAIL EMPLOYMENT BY REGION

$(1929=100)$

\begin{tabular}{lccc}
\hline \multicolumn{1}{c}{ Region } & 1933 & 1935 & 1939 \\
\hline New England & 82.3 & 92.0 & 102.5 \\
Middle Atlantic & 79.5 & 91.2 & 100.5 \\
East North Central & 77.7 & 87.0 & 104.1 \\
West North Central & 80.9 & 88.9 & 100.8 \\
South Atlantic & 89.5 & 104.4 & 130.0 \\
East South Central & 77.3 & 88.6 & 108.5 \\
West South Central & 78.5 & 88.1 & 112.8 \\
Mountain & 73.8 & 88.0 & 113.8 \\
Pacific & 80.8 & 92.3 & 115.7 \\
\hline
\end{tabular}

Sources: U.S. Department of Commerce, Bureau of the Census, Census of American Business, p. 4, and Census of Business, pp. 60-62.

the South Atlantic division after 1929 is evident. Regional differences in manufacturing employment were also mirrored in the behavior of total output and per-capita income. ${ }^{8}$

The aggregate census employment and production data summarized in Figures 1 and 2 suggest three stylized facts: the magnitude of the contraction and recovery was quite similar across much of the country, despite considerable differences in industrial structure across regions; the South Atlantic division experienced a milder downturn and recovered more rapidly than the rest of the country; and employment losses were severe and relatively persistent in the Mountain states.

What might explain the observed geographical variations in the severity of the Depression? Most accounts of the causes of the Depression focus on the role of large national shocks to aggregate demand. Among the potential sources of such shocks are tight monetary policy; monetary disturbances caused by the 1929 stock market crash and the bank failures of the early thirties; increased uncertainty in the wake of the stock market crash; and unexplained shocks to consumption or investment. ${ }^{9}$ In addition, supply effects operating through changing market structure or the pace of technological change may have contributed to the severity of the Depression. ${ }^{10}$

Although these shocks would have been national in scope, their propagation into aggregate disturbances in prices and quantities is likely to have varied by location because of locational differences in industrial structure, economic institutions, or other economic conditions. One of the most likely

\footnotetext{
"See Schmitz and Fishback, "Distribution."

9 On tight monetary policy, see Friedman and Schwartz, Monetary History; Hamilton, "Monetary Factors"; and Temin, Lessons. On monetary disturbances, see Friedman and Schwartz, ibid.; and Field, "Asset Exchanges." On increased uncertainty, see Romer, "Great Crash." On unexplained shocks, see Temin, Did Monetary Forces.

${ }^{10}$ Bernstein, Great Depression; and Szostak, Technological Innovation.
} 
sources of regional differences is variation in industry composition. Shocks to aggregate demand have differential effects by industry. As consumer incomes fall, the demand for relatively more income-elastic goods should fall relatively further; as real interest rates rise or future incomes become more uncertain, the demand for durables should decline relatively more than the demand for nondurables. Industries that produce inputs for industries with more volatile demand are themselves more likely to experience severe demand shocks. National economic policies also may affect industries differently. Barbara Alexander and Matthew Krepps, for example, report that the effectiveness of industry codes adopted following passage of the National Industrial Recovery Act (NIRA) in 1933 varied across industries depending on market structure and product characteristics. "Finally, technology shocks are also likely to vary across industries. Borts and Wallis find that industry composition contributed significantly to locational variation during the Great Depression, although location-specific effects remain even after controlling for industry composition. ${ }^{12}$

The effects of demand shocks on highly cyclical industries could be transmitted to other local industries in a variety of ways. Employment reductions would reduce worker incomes for purchases of consumer goods produced locally. Stress on local financial markets may also have spread shocks across industries. Banking panics, for example, at least before 1933, were essentially local and regional affairs and were concentrated in farming areas, especially in the East and West North Central and southern divisions of the country. ${ }^{13}$ Thus shocks to the money supply could have varied regionally. Furthermore, as Bernanke has argued, banking crises not only reduced the money supply but also disrupted the operation of local capital markets. ${ }^{14}$ Thus access to capital was disrupted for an entire local economy during a banking crisis. ${ }^{15}$

Additional potential sources of regional variation include geographical differences in wealth or wealth distribution and in the impact of government expenditures or market interventions. To the extent that consumption expen-

"Alexander, "Failed Cooperation"; and Krepps, "Another Look."

${ }^{12}$ Both Borts ("Regional Cycles") and Wallis ("Employment") measure the effect of industry structure by comparing actual employment behavior across states to a counterfactual in which each industry is assigned its national rate of employment reduction and then weighted by the state's industry composition. Unfortunately, this method is biased toward finding a strong industry composition effect. Suppose, for example that within a region all industries have the same rate of employment loss, but some regions experience a larger employment decline than others. Industries concentrated in the more volatile region will appear more volatile, with the result that some of the decline in employment will be mistakenly assigned to industry mix, when in fact all industries within a region experienced the same reduction in employment. Only by controlling simultaneously for location and industry can the contribution of industrial composition be estimated accurately.

${ }^{13}$ Chandler, America's Greatest Depression, pp. 83, 84; and Wicker, Banking Panics.

${ }^{14}$ Bernanke, "Nonmonetary Effects."

${ }^{15}$ For modern evidence of such a regional credit channel, see Samolyk, "Banking Conditions." 
ditures fell due to the wealth effect of declining asset values, the shock to consumption could have varied with regional variations in wealth or its distribution. Government expenditures varied across states, partly for political reasons. ${ }^{16}$ The impact of New Deal regulations differed not only by industry, as noted above, but also by region. Gavin Wright, for example, notes that the minimum wages established under the NRA and later the Fair Labor Standards Act were binding for a larger percentage of workers in the lowwage South. ${ }^{17}$

A full assessment of all the major potential causes of regional variation in the impact of the Depression is beyond the scope of the present article. Instead, we focus on quantifying the relative importance of industry structure and region-specific effects. If industry mix accounts for most of the observed regional variation, we may conclude that the Depression was essentially a national phenomenon that was transmitted to the regions via industry-specific shocks.

\section{THE DATA}

Our panel data set is based on the published reports of the biennial Census of Manufactures for the years 1919 through $1937 .{ }^{18}$ We collected data for all 48 states (District of Columbia excluded) and for 20 industries. The industries chosen were the 20 largest (ranked by number of wage earners employed in 1929) for which we could construct a reasonably consistent series for the entire period, using the census classification scheme of the period. Shifts in the definition and constituent industries for certain industry groups precluded using them in the sample. The 20 industries selected for our sample were, however, all within the top 31 manufacturing industries nationally in 1929. Table 2 lists the 31 largest industries according to employment and gives sample employment and coverage for those included in the study.

For each state-industry observation in each year, we recorded the number of establishments, the average number of wage earners (employment), and the total dollar value for the census year of compensation of wage earners, cost of materials, and value of production. The Census calculated average annual employment in an establishment as the average of 12 monthly figures, where each month's employment was the number of wage earners on the payroll "for the week which included the 15th day of each month, or for some other representative week." 19

\footnotetext{
${ }^{16}$ Wright, "Political Economy."

${ }^{17}$ Wright, Old South.

${ }^{12}$ Although we also collected observations for 1939, extensive changes in the industry definitions between the 1937 and 1939 censuses raised serious questions about the comparability of the data between those years. We have excluded 1939 from the present analysis.

${ }^{19}$ U.S. Department of Commerce, Fifieen Census, p. 5.
} 
TABLE 2

TOP 31 MANUFACTURING INDUSTRIES NN 1929, RANKED BY EMPLOYMENT

\begin{tabular}{|c|c|c|c|c|}
\hline Rank & Industry & $\begin{array}{c}\text { Number of } \\
\text { Wage } \\
\text { Earners }\end{array}$ & $\begin{array}{c}\text { Sample } \\
\text { Employment }\end{array}$ & $\begin{array}{c}\text { Proportion } \\
\text { Covered }\end{array}$ \\
\hline 1 & Foundry and machine-shop products & 454,441 & & \\
\hline 2 & Cotton goods & 424,916 & 411,977 & 0.970 \\
\hline 3 & Lumber and timber products & 419,084 & 418,539 & 0.999 \\
\hline 4 & Iron and steel: steel works and rolling mills & 394,574 & 369,197 & 0.936 \\
\hline 5 & Car and general construction and repairs, steam RR & 368,681 & & \\
\hline 6 & Electrical machinery & 328,722 & & \\
\hline 7 & Motor vehicles & 226,116 & 207,079 & 0.916 \\
\hline 8 & Motor vehicles, bodies and parts & 221,332 & 218,275 & 0.986 \\
\hline 9 & Knit goods & 208,488 & & \\
\hline 10 & Boots and shoes other than rubber & 205,640 & 202,608 & 0.985 \\
\hline 11 & Bread and other bakery products & 200,841 & 199,495 & 0.993 \\
\hline 12 & Furniture & 193,399 & 193,256 & 0.999 \\
\hline 13 & Clothing, women's & 187,500 & & \\
\hline 14 & Printing and publishing, book and job & 150,649 & & \\
\hline 15 & Clothing, men's & 149,868 & & \\
\hline 16 & Silk and rayon & 130,467 & & \\
\hline 17 & Printing and publishing, newspapers and periodicals & 129,660 & 128,315 & 0.990 \\
\hline 18 & Meatpacking, wholesale & 122,505 & 119,032 & 0.972 \\
\hline 19 & Cigars and cigarettes & 105,308 & 98,715 & 0.937 \\
\hline 20 & Paper & 103,320 & 101,343 & 0.981 \\
\hline 21 & Canning and preserving & 98,866 & 98,693 & 0.998 \\
\hline 22 & Clay products & 93,336 & & \\
\hline 23 & Planing-mill products & 90,134 & 89,770 & 0.996 \\
\hline 24 & Worsted goods & 88,485 & & \\
\hline 25 & Rubber tires and inner tubes & 83,263 & 68,398 & 0.821 \\
\hline 26 & Petroleum refining & 80,596 & 73,487 & 0.912 \\
\hline 27 & Dyeing and finishing textiles & 79,327 & & \\
\hline 28 & Nonferrous metals & 79,183 & 73,558 & 0.929 \\
\hline 29 & Glass & 67,527 & 62,548 & 0.926 \\
\hline 30 & Confectionery & 63,501 & 63,176 & 0.995 \\
\hline 31 & Chemicals & 62,199 & 58,739 & 0.944 \\
\hline
\end{tabular}

Source: U.S. Department of Commerce, Bureau of the Census, Fifteenth Census of the United States, Manufactures: 1929 , table 6.

The employment numbers suffer from various potential biases. The Census warned that several of these biases would likely inflate the employment numbers beyond full-time equivalent employment: part-time employees may have been counted the same as full-time employees; establishments that were shut down on the fifteenth of the month might have selected a different week as more "representative"; and some employees who had been laid off or terminated might have remained on the payroll for a period, even if they were not actually at work.

It seems likely that all of these biases dampen the employment fluctuations reported in the Census relative to the actual fluctuations, and thus the 
employment data are likely to understate the size of employment losses during the contraction of the early 1930s. Furthermore, the Census did not systematically report weekly working hours, so the employment numbers do not completely reflect movements in total labor hours. Cyclical adjustments in weekly hours were relatively larger during the interwar period than they have been in postwar cycles. ${ }^{20}$ Unless there were good reason to believe that these biases operated differentially by region, however, the data should still be useful in examining the sources of regional variations in employment fluctuations. Furthermore, we can compare the results using employment as the dependent variable with those using total product value, which should not be subject to the same biases. From Figure 2 it is clear that the overall regional patterns for product value closely resemble those for employment.

Clearly, our sample is not a random sample of manufacturing industries or establishments. Some of the most important U.S. industries-such as the single largest employer, foundries and machine shops, and the clothing industries-are not represented in our sample; nor are the numerous smaller, more specialized industries. Still, the sample represents a large percentage of U.S. manufacturing workers in a wide range of industries, including both consumer and producer goods and durables and nondurables.

Another shortcoming of the data is its low frequency (biennial). We cannot capture details of the timing of the Depression that are available to researchers who use monthly series. Still, the biennial observations coincide roughly with well-known cyclical turning points, such as the trough of the $1920 / 21$ depression, the pre-Depression peak in 1929, and the trough of the Great Contraction in 1933. It should also be noted that the other major Depression-decade manufacturing data set that is disaggregated to the state level-John Wallis's-is benchmarked to the biennial Census of Manufactures, and thus "movements in [his] manufacturing series [correspond] to the Census of Manufactures between all odd-numbered years."21

To maintain the confidentiality of business establishments, the census did not report details for establishments in states with very few firms in a given industry. As a result, our data set has missing values for certain industrystate cells. Nevertheless, the coverage of our sample is quite good for each of the 20 industries. Table 2 also reports the proportion of total U.S. industry employment covered by non-missing observations in our sample. Coverage exceeds 80 percent in all 20 industries and 90 percent in all but one of them.

The regional coverage of the data is presented in Table 3, which shows the number of wage earners in our sample as a percentage of all manufacturing wage earners, by census division, for the beginning, middle (1929), and end of our panel. For the United States as a whole, our sample covers a little over

${ }^{20}$ Bernanke and Powell, "Cyclical Behavior."

${ }^{21}$ Wallis, "Employment," p. 50. 
TABLE 3

EMPLOYMENT IN A 20-INDUSTRY SAMPLE AS A PERCENTAGE OF TOTAL MANUFACTURING EMPLOYMENT

\begin{tabular}{llcl}
\hline \hline \multicolumn{1}{c}{ Region } & 1919 & 1929 & 1937 \\
\hline South Atlantic & 48.6 & 51.9 & 49.6 \\
East South Central & 44.1 & 38.4 & 29.9 \\
West South Central & 50.2 & 46.2 & 46.2 \\
Pacific & 40.6 & 53.4 & 55.1 \\
Mountain & 28.6 & 36.9 & 43.1 \\
West North Central & 32.8 & 33.4 & 38.6 \\
East North Central & 35.2 & 40.0 & 42.7 \\
New England & 33.0 & 29.6 & 24.5 \\
Middle Atlantic & 25.3 & 26.5 & 26.4 \\
United States & 33.8 & 36.5 & 36.8 \\
\hline
\end{tabular}

Source: U.S. Dept. of Commerce, Census of Manufactures, 1919, 1929, and 1937.

one-third of manufacturing wage earners. Coverage varies but is at least 24 percent in every region. Table 3 indicates that between 1919 and 1937 there were significant changes in our sample's coverage in four of the nine divisions. Coverage fell substantially in the East South Central and New England divisions and rose substantially in the Pacific and Mountain divisions. The declining coverage of our sample in the East South Central is accounted for almost entirely by the dramatic collapse of employment in the lumber industry there. As we note below, this imparts a bias toward excessive volatility in our sample for that division. In New England, the drop in coverage is again attributable largely to one industry-in this case, cotton textiles. In the Pacific and Mountain regions, the rising coverage of our sample seems to be due to a relative decline in employment in industries outside our sample. ${ }^{22}$

For our purposes, the validity of the data depends primarily on whether they reasonably track the cyclical movement of employment and other variables, as well as the regional variation in those movements. Figure 3 plots percentage changes in employment for each census year in our sample, comparing total U.S. manufacturing with the employment recorded in our sample. ${ }^{23}$ The sample tracks changes in total manufacturing employment quite well. Similar figures for regional subsamples are presented in an appendix available from the authors. Although there are somewhat larger deviations between the regional subsamples and the manufacturing totals, the sample again does a reasonable job tracking the aggregate movements in most regions. The most important exception is the East South Central, in which our sample shows a much larger employment reduction between 1929

\footnotetext{
${ }^{22}$ This can be inferred from the fact that employment in most of the individual sample industries is an increasing percentage of total manufacturing employment in these two divisions.

${ }^{23}$ The percentage change for year $t$ is the natural log of employment in year $t$ minus the natural log of employment in year $t-1$.
} 


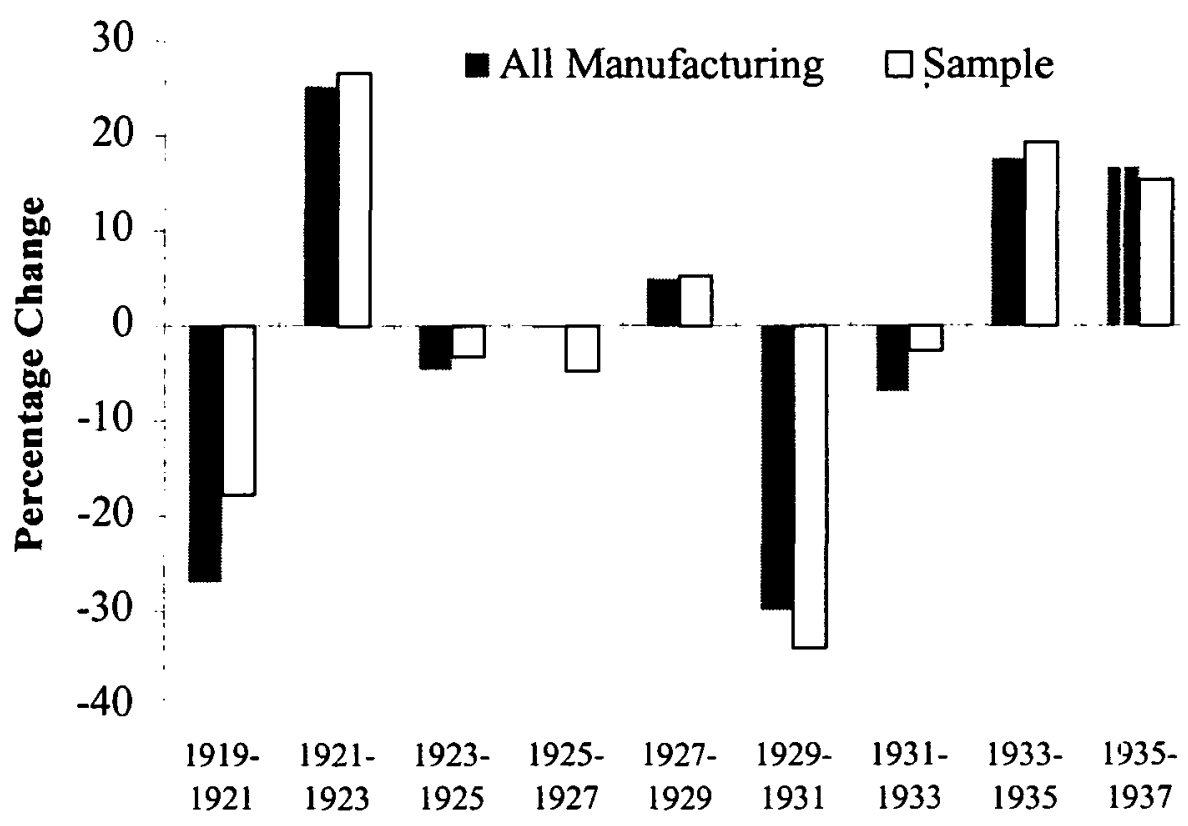

FIGURE 3

EMPLOYMENT CHANGES FOR ALL MANUFACTURING AND 20-INDUSTRY SAMPLE

Notes: The All Manufacturing series uses 1935 employment that is consistent with earlier years in industrial coverage. Proportional changes are calculated as the change in natural log of employment. Sources: U.S. Department of Commerce, Census of Manufactures (various years); see the text for details on the 20-industry sample.

and 1931 than was true for manufacturing as a whole. In the Mountain and West North Central divisions, the timing of the 1929 to 1933 contraction differs between the sample and all manufacturing, although the total reductions over the four-year period are of similar magnitude. To summarize, our sample seems to provide a reasonable representation of employment movements in the manufacturing sector, with the exception of the East South Central division.

\section{A PANEL ANALYSIS OF THE INDUSTRY-STATE DATA}

Changes in economic activity during the Depression varied by location, industry, and time period. Furthermore, these variations may have included both trend changes and cyclical variations around trend. For example, a relatively large decrease in employment in a particular region during the 1929 to 1933 contraction could have been due to a strong region-specific cyclical shock, slower trend growth in regional employment, or both. In this section we present an empirical regression model for our panel data that 
allows us to estimate the separate effects of both trend and cyclical changes associated with industries and regions. By doing so, we can determine the extent to which regional variation in the severity of the Depression was the consequence of variation in region-specific cyclical effects, time trends, or variation due to differences in the industrial composition of regional economies.

The dependent variable in our analysis is the percentage change (change in the natural $\log$ ) in employment between two biennial manufacturing censuses. The analysis can also be performed for other variables of interest, such as annual production value or annual wage payments per worker, which we summarize later in the article. For employment, we define the dependent variable as

$$
e_{i s t} \equiv \ln \left(E_{i s t}\right)-\ln \left(E_{i s, t-1}\right)
$$

where $E_{\text {ist }}$ is employment in industry $i(i=1, \ldots, I)$, state $s(s=1, \ldots, S)$, and time period $t(t=1, \ldots, T)$, with the unit of time being two years.

The regression model uses dummy variables to capture the effects of industry $\left(h_{\mathrm{i}}\right)$, region $\left(z_{\mathrm{n}}\right)$, and time $\left(b_{\mathrm{t}}\right)$, as well as the interactions between industry and time $\left(f_{\mathrm{it}}\right)$ and region and time $\left(g_{\mathrm{nt}}\right)$. The model, then, is

$$
e_{i s t}=c+h_{i}+z_{n}+b_{t}+f_{i t}+g_{n t}+u_{i s t}
$$

where $n=1, \ldots, N$ indexes the region, and $u_{\text {ist }}$ is an error term. We omit interactions between industry and region, which would provide estimates of separate time trends for specific industry-region combinations. As we later note (see note 26), these interaction terms are not significantly different from zero in our analysis of variance.

Identification of the model requires imposing identifying restrictions on the dummy variables. Usually this is accomplished by dropping one category for each set of dummies, in which case the intercept becomes the value of the excluded category. Instead, we restrict the mean effect of each set of dummy variables to be zero. In other words, the model makes the sample average the reference point for the dummy variables, rather than an arbitrarily excluded region, industry, and time period. ${ }^{24}$ This specification eases interpretation of the results, but it has no effect on the estimated relative effects; indeed, the coefficients we estimate can readily be transformed into those obtained from the conventional restrictions.

\footnotetext{
${ }^{24}$ Marimon and Zilibotti, "“Actual' Versus 'Virtual' Employment," p. 5.
} 
The following restrictions imply that the mean coefficient effects are zero

$$
\begin{array}{ll}
\sum_{i} h_{i}=0 & \\
\sum_{n} z_{n}=0 & \\
\sum_{t} b_{t}=0 & \\
\sum_{i} f_{i t}=0 & \forall_{t=1, \ldots, T} \\
\sum_{t} f_{i t}=0 & \forall_{i=1, \ldots, I} \\
\sum_{n} g_{n t}=0 & \forall_{t=1, \ldots, T} \\
\sum_{t} g_{n t}=0 & \forall_{n=1, \ldots, N}
\end{array}
$$

Because the dependent variable is the percentage change in employment, the constant term under our specification (equation 1) represents the (unweighted) average time trend in employment growth over the whole sample period, while the effects $h_{\mathrm{i}}$ and $z_{\mathrm{n}}$ capture the deviations of industry-specific and region-specific trends from the average or baseline trend. The timeperiod dummy variables $\left(b_{t}\right)$ represent average year-specific effects and thus can be thought to capture cyclical movements around the trend that are common to all industries and regions. Finally, the interaction effects $f_{\mathrm{it}}$ and $g_{\mathrm{nt}}$ capture cyclical variations around trend that are specific to individual industries and regions respectively. If, for example, the coefficient $g$ were more negative for region $\mathrm{A}$ than for region $\mathrm{B}$, it would imply that the cyclical downturn was more severe in region $A$, even after controlling for regional differences in industry composition.

\section{RESULTS: EMPLOYMENT}

Results for employment growth rates are summarized in Tables 4 and 5 . Table 4 is a partial ANOVA table for the model. Approximately 40 percent of the variation in employment growth rates is explained by the model. The $F$ statistics indicate that all the sets of variables, including the interactions, are statistically significant in explaining employment growth. Examining the column for sum of squares, it is evident that the year effects $\left(b_{t}\right)$ and yearby-industry interactions $\left(f_{i t}\right)$ account for the lion's share of the explained variation. In other words, year-to-year variations around trend in employ- 
TABLE 4

ANOVA FOR PANEL MODEL OF EMPLOYMENT GROWTH RATE

\begin{tabular}{lrrrrrl}
\hline Source & Partial SS & \multicolumn{1}{c}{ df } & \multicolumn{1}{c}{ MS } & \multicolumn{1}{c}{ F } & Prob $>$ F & \\
\hline Model & 299.28 & 250 & 1.197 & 11.50 & 0.000 \\
Year & 81.49 & 8 & 10.187 & 97.86 & 0.000 & \\
Region & 4.09 & 8 & 0.512 & 4.92 & 0.000 \\
Ind & 14.95 & 19 & 0.787 & 7.56 & 0.000 & \\
Year*region & 16.66 & 64 & 0.260 & 2.50 & 0.000 & \\
Year*ind & 119.01 & 151 & 0.788 & 7.57 & 0.000 & \\
Residual & 464.90 & 4,466 & 0.104 & & & \\
Total & 764.18 & 4,716 & 0.162 & & & 4,717 \\
$N$ & & & & & & 0.3916 \\
$R$-squared & & & & & & 0.32264 \\
Root MSE & & & & & & \\
Adjusted & & & & & & \\
\multicolumn{1}{l}{$R$-squared } & & & & & & \\
\hline
\end{tabular}

Note: ANOVA estimate using 20 -industry sample (see the text).

ment for the economy as a whole and the industry-specific deviations from those fluctuations are the major source of explained variation in our sample. ${ }^{25}$ Region effects, both trend and cycle, are statistically significant, but account for less of the variation in employment growth. ${ }^{26}$

Table 5 summarizes the results of estimating equation 1 using unweighted ordinary least squares. The first column gives the estimated trend coefficients for average or baseline employment growth (the constant term), region-specific trends $\left(z_{\mathrm{n}}\right)$, and industry-specific trends $\left(h_{\mathrm{i}}\right)$. The remaining columns give the estimates of the year-specific effects for the baseline $(b)$, region-time interactions $\left(g_{\mathrm{nt}}\right)$, and industry-time interactions $\left(f_{\mathrm{it}}\right) .{ }^{27}$

The estimated baseline trend (0.004) implies an average biennial growth rate of just 0.4 percent, a negligible rate of employment growth. Continuing down the first column, the regional trends show considerable variation. All three southern regions were regions of above-average growth, controlling for industry composition, as was the west coast (Pacific). Manufacturing employment grew more slowly than average in the industrial northeast (New England and Middle Atlantic), and in the West North Central and Mountain regions.

The year-to-year deviations from trend show the expected patterns. Reading across the first row of Table 5, the severe contraction of the 1919 to 1921 period is evident, as is the recovery that followed. The dramatic employment reductions of the "great contraction" between 1929 and 1933 also show up clearly. Looking at the region cycle effects there is some evidence of regional differences in the magnitude of cyclical movements, with the 1929 to

${ }^{25}$ This result is consistent with the findings of Ghosh and Wolf, "Geographical and Sectoral Shocks," using data from 1963 through 1991.

${ }^{26}$ Interaction terms between industry and region are not significantly different from zero when added to the ANOVA, suggesting that industry trends did not vary systematically across regions.

${ }^{27}$ Standard errors and estimated $t$-statistics are reported in an appendix available from the authors. 


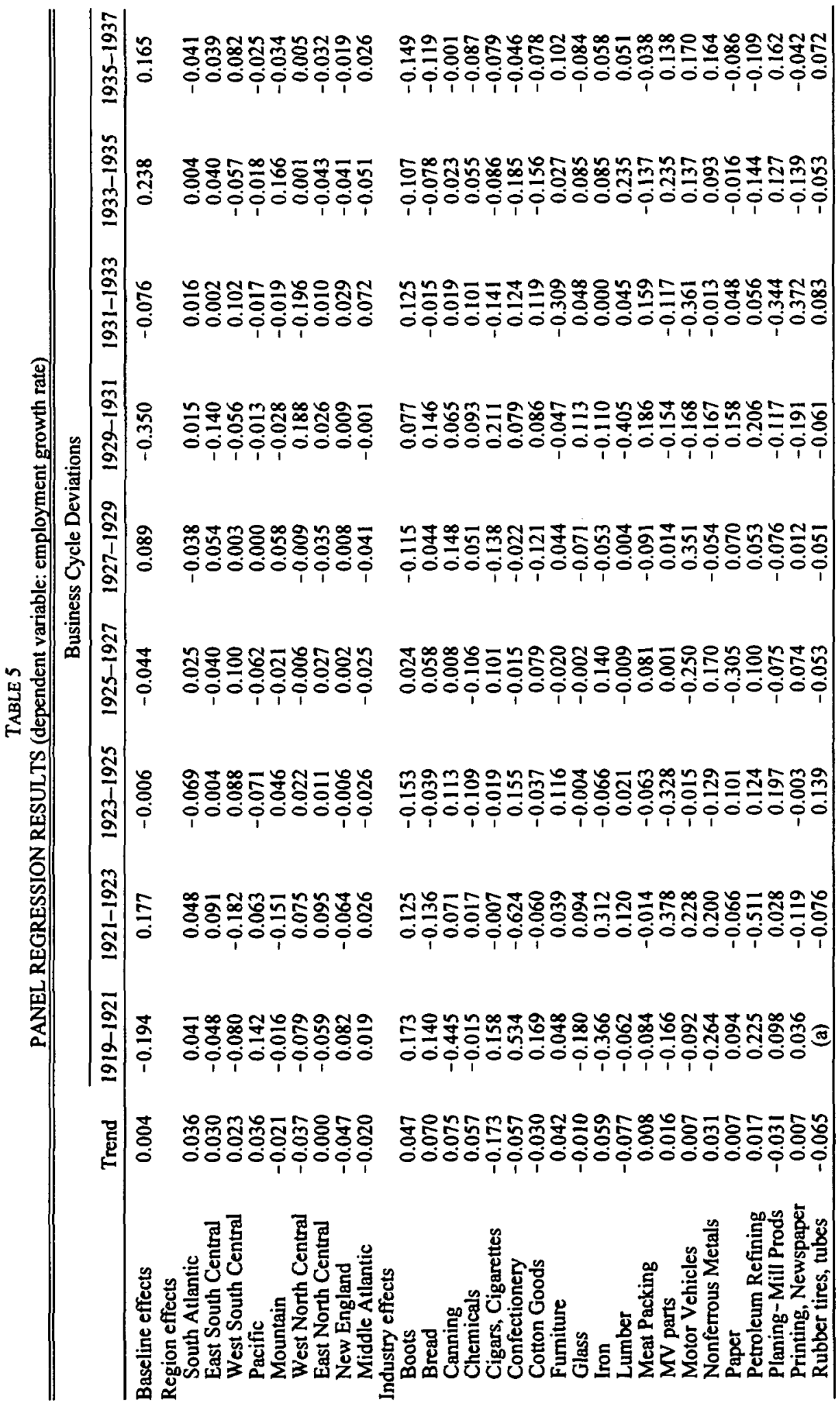


TABLE 5 - continued

(a) Coefficient could not be estimated because of missing data.

Notes: Estimated OLS coefficients from panel regression model (see text).

1931 downturn being much stronger in the East South Central, and much milder in the West North Central divisions. The industry cycle effects reveal quite pronounced and relatively systematic differences in the movements of employment in individual industries. For the most part, the industry effects in both the 1919 to 1921 and 1929 to 1933 downturns are consistent with the view that employment fluctuations in durable goods industries were more volatile than overall manufacturing employment over the cycle, whereas nondurable goods industries were less volatile.

Our interpretation of the coefficients in the first column of the table as estimates of trend employment growth is open to the criticism that our sample period of two decades is simply too short to identify a genuine trend, particularly considering the fact that the second half of the period is dominated by the Great Depression. Regions exhibiting slow "trend" growth in employment in our sample may actually be regions that were especially hard hit by the Depression, with the consequence that the estimated trend over two decades is negative. If this were true, it would make little sense to claim a sharp distinction between trend and cycle in our results.

In fact, our estimates of the regional trends are largely robust to changing the sample period, including estimating the trend on the pre-Depression data alone. Table 6 presents regional trend coefficients estimated using alternative sample periods. The first alternative drops the 1919 to 1921 observations, thus beginning the sample in the 1921 trough. This has virtually no effect on the variation in regional trends. The second alternative estimates the trend using only the 1921 to 1929 observations, thus dropping the Depression years altogether. Although the East South Central does a little better and the West South Central a little worse in this sample, the basic regional pattern of trends remains remarkably similar to that based on the full-sample estimates. The last column of Table 6 offers another indicator of regional trends in employment: the percentage change in total manufacturing employment between 1919 and 1947. The basic regional pattern is overall quite similar to that indicated in our trend estimates. We thus are confident that what we have termed regional trend growth rates are capturing more than regional differences in the severity of the Depression itself.

Accounting for Regional Differences in Employment Growth During the Depression

The most substantial regional differences revealed in Figure 1 are the milder contraction of employment in the South Atlantic region and the more 
TABLE 6

ESTIMATED REGIONAL TREND COEFFICIENTS UNDER ALTERNATIVE SAMPLE PERIODS AND GROWTH OF TOTAL MANUFACTURING EMPLOYMENT, 1919-1947

\begin{tabular}{|c|c|c|c|c|}
\hline \multirow[b]{2}{*}{ Region } & \multirow{2}{*}{$\begin{array}{c}\text { Full Sample } \\
1919-1937\end{array}$} & \multicolumn{2}{|c|}{ Alternative Sample Periods } & \multirow{2}{*}{$\begin{array}{l}\text { Employment Growth } \\
\text { (percentage) } \\
1919-1947\end{array}$} \\
\hline & & $1921-1937$ & $1921-1929$ & \\
\hline South Atlantic & 0.0355 & 0.0381 & 0.0361 & 49.8 \\
\hline East South Central & 0.0301 & 0.0249 & 0.0452 & 52.8 \\
\hline West South Central & 0.0228 & 0.0128 & 0.0086 & 46.9 \\
\hline Pacific & 0.0363 & 0.0403 & 0.0478 & 53.9 \\
\hline Mountain & -0.0207 & -0.0161 & -0.0377 & 6.2 \\
\hline West North Central & -0.0368 & -0.0371 & -0.0362 & 24.1 \\
\hline East North Central & 0.0003 & 0.0046 & 0.0082 & 39.7 \\
\hline New England & -0.0468 & -0.0441 & -0.0423 & -7.9 \\
\hline Middle Atlantic & -0.0205 & -0.0234 & -0.0296 & 12.9 \\
\hline United States & & & & 27.0 \\
\hline
\end{tabular}

Notes: Trend coefficients from OLS regressions using 20-industry sample. Employment growth measured as the change in the natural log of total manufacturing employment. Employment is number of wage earners in all years except 1947, when it is number of production workers.

Sources for employment growth: U.S. Dept. of Commerce, Bureau of the Census, Abstract of the Census of Manufactures, 1919, p. 280. U.S. Dept. of Commerce, Bureau of the Census, Census of Manufactures: 1947, Volume I, General Summary, p. 32.

severe and prolonged contraction in the Mountain region. Our panel analysis allows us to examine the role of regional trends and cyclical shocks as well as industry composition in generating these regional differences.

In Table 7 we summarize the percentage changes in employment for the 1929 to 1933 contraction, the 1933 to 1937 recovery, and the full 1929 to 1937 swing, and decompose these changes into region and industry effects. The first column shows the actual changes in employment in our sample, by region and for the United States as a whole. The second column gives the deviation of the regional change from the U.S. total. The South Atlantic's milder contraction is indicated by the 14-percentage-point differential between its employment change and the U.S. average during the period from 1929 to 1933. By contrast, the East South Central and Mountain divisions show the most substantial negative deviations during the downturn. During the recovery period (1933 to 1937), the Mountain region bounced back substantially, whereas the East South Central remained severely depressed. The results for the East South Central division must be treated with caution, however, to the extent that our sample overstates the size of the employment contraction there (see the earlier section on data). New England, which had a relatively mild contraction, had essentially no employment recovery in our sample.

Taking a longer view, the bottom third of the table shows that between 1929 and 1937 there was considerable regional variation in employment growth. With the exception of the anomalous East South Central division, the South fared somewhat better than the national average, as did the Pacific 
TABLE 7

ACCOUNTING FOR REGIONAL DIFFERENCES IN EMPLOYMENT GROWTH, 1929-1937 (percentages)

\begin{tabular}{|c|c|c|c|c|c|c|c|c|c|}
\hline & \multirow{2}{*}{$\begin{array}{l}\text { Actual } \\
\text { Change }\end{array}$} & \multirow{2}{*}{$\begin{array}{l}\text { Region } \\
\text { - USA }\end{array}$} & \multicolumn{3}{|c|}{ Region Effects } & \multicolumn{3}{|c|}{ Industry Effects } & \multirow{2}{*}{$\begin{array}{l}\text { Region + } \\
\text { Industry }\end{array}$} \\
\hline & & & Trend & Cycle & Total & Trend & Cycle & Total & \\
\hline \multicolumn{10}{|c|}{$1929-1933$} \\
\hline South Atlantic & -22.7 & 14.2 & 7.1 & 3.0 & 10.1 & -6.0 & 5.6 & -0.4 & 9.7 \\
\hline East South Central & -68.8 & -31.9 & 6.0 & -13.8 & -7.8 & -6.5 & -14.2 & -20.7 & -28.5 \\
\hline West South Central & -38.7 & -1.8 & 4.6 & 4.6 & 9.2 & -3.8 & -2.0 & -5.7 & 3.5 \\
\hline Pacific & -43.0 & -6.0 & 7.3 & -2.9 & 4.3 & -2.8 & -13.2 & -16.0 & -11.7 \\
\hline Mountain & -65.9 & -29.0 & -4.1 & -4.7 & -8.8 & -4.9 & -8.4 & -13.3 & -22.1 \\
\hline West North Central & -32.0 & 4.9 & -7.4 & -0.8 & -8.2 & 3.9 & 10.9 & 14.8 & 6.6 \\
\hline East North Central & -39.5 & -2.6 & 0.0 & 3.6 & 3.6 & 3.4 & -11.0 & -7.6 & -4.0 \\
\hline New England & -25.1 & 11.9 & -9.4 & 3.8 & -5.5 & 1.4 & 13.2 & 14.6 & 9.0 \\
\hline Middle Atlantic & -40.9 & -3.9 & -4.1 & 7.1 & 3.1 & 3.7 & 0.9 & 4.6 & 7.7 \\
\hline United States total & -36.9 & & & & & & & & \\
\hline \multicolumn{10}{|c|}{$1933-1937$} \\
\hline South Atlantic & 24.5 & -10.2 & 7.1 & -3.7 & 3.4 & -3.8 & -9.9 & -13.7 & -10.3 \\
\hline East South Central & 39.8 & 5.2 & 6.0 & 7.8 & 13.9 & -4.4 & 7.6 & 3.2 & 17.1 \\
\hline West South Central & 41.9 & 7.2 & 4.6 & 2.5 & 7.1 & -1.6 & -0.8 & -2.4 & 4.6 \\
\hline Pacific & 45.7 & 11.0 & 7.3 & -4.3 & 2.9 & -0.2 & 10.2 & 10.0 & 13.0 \\
\hline Mountain & 54.9 & 20.3 & -4.1 & 13.2 & 9.0 & -0.4 & 3.1 & 2.7 & 11.8 \\
\hline West North Central & 31.1 & -3.6 & -7.4 & 0.5 & -6.8 & 5.0 & -12.8 & -7.9 & -14.7 \\
\hline East North Central & 47.1 & 12.4 & 0.0 & -7.5 & -7.5 & 4.1 & 10.9 & 15.0 & 7.6 \\
\hline New England & -0.8 & -35.5 & -9.4 & -6.0 & -15.4 & 2.1 & -14.9 & -12.8 & -28.2 \\
\hline Middle Atlantic & 33.3 & -1.4 & -4.1 & -2.5 & -6.6 & 6.1 & -1.7 & 4.4 & -2.2 \\
\hline United States total & 34.7 & & & & & & & & \\
\hline \multicolumn{10}{|c|}{$1929-1937$} \\
\hline South Atlantic & 1.8 & 4.0 & 14.2 & -0.7 & 13.5 & -10.8 & -3.9 & -14.8 & -1.3 \\
\hline East South Central & -29.0 & -26.7 & 12.0 & -6.0 & 6.0 & -11.5 & -5.5 & -17.0 & -10.9 \\
\hline West South Central & 3.1 & 5.4 & 9.1 & 7.1 & 16.3 & -6.4 & -3.3 & -9.7 & 6.5 \\
\hline Pacific & 2.7 & 4.9 & 14.5 & -7.2 & 7.3 & -4.1 & -3.0 & -7.1 & 0.2 \\
\hline Mountain & -11.0 & -8.7 & -8.3 & 8.5 & 0.2 & -8.2 & -2.8 & -10.9 & -10.7 \\
\hline West North Central & -1.0 & 1.3 & -14.7 & -0.2 & -15.0 & 8.4 & 0.7 & 9.1 & -5.9 \\
\hline East North Central & 7.6 & 9.8 & 0.1 & -3.9 & -3.8 & 7.4 & -1.5 & 5.9 & 2.1 \\
\hline New England & -25.9 & -23.6 & -18.7 & -2.2 & -20.9 & 3.4 & -2.0 & 1.4 & -19.5 \\
\hline Middle Atlantic & -7.6 & -5.3 & -8.2 & 4.6 & -3.5 & 8.6 & -0.2 & 8.4 & 4.9 \\
\hline United States total & -2.3 & & & & & & & & \\
\hline
\end{tabular}

Notes: Decomposition of effects based on regression estimates from Table 5.

and East North Central. The Mountain and New England divisions lagged in employment growth over the eight-year period.

To account for the regional deviations, we use the regression coefficients from the panel model to predict the impact of pure regional effects as well as industry composition on regional employment, net of the national average trend and cycle. These effects are summarized in the third through ninth columns of Table 7. Under the heading "Region Effects," the trend effect is the regional trend coefficient $z_{\mathrm{n}}$, compounded over the relevant number of 
periods, while the cycle effect is the sum of the region-specific year effects $g_{\text {nt }}$ for the relevant periods.

The effects of industry composition are calculated from counterfactual regional employment, using the trend or cycle industry coefficients weighted by the regional employment in each industry in the initial year. ${ }^{28}$ Because the estimated industry trend and cycle effects are (by construction) common to all regions, the industry effects will differ across regions only because of differences in the relative employment shares of each industry in the different regions. The counterfactual employment levels due to industry trends $\left(E^{*}{ }_{\text {trend }}\right)$ and industry cycles $\left(E_{\text {cycle }}^{*}\right)$ are given by

$$
E_{\text {trend }}^{*}=\sum_{i} e^{h_{i}} E_{i n, t-1} \quad E_{c y c l e}^{*}=\sum_{i} e^{f_{i r}} E_{i n, t-1}
$$

The industry effects presented in the table are the percentage change in employment between the actual value at time $t-1$ and the counterfactual value at time $t$; for example, the trend effect for region $n$ is $\ln \left(E^{*}{ }_{\text {rend }}\right)-\ln \left(E_{n, t-1}\right) .^{29}$

The final column of the table adds up the region and industry effects. The sum of the effects can be viewed as a rough indication of how well these effects explain the region's deviation from the national average employment growth, because they are calculated leaving out the common trend and cycle effects. Thus the final column should be compared with the second column. Differences between the second and final columns of the table are presumably due to the effects of interactions between industry and region that we have not captured in the model.

As the estimates for the 1929 to 1933 contraction show, the region effects are particularly important in explaining the relative mildness of the contraction in the South Atlantic, and it is the upward trend of employment in the region that does most of the work. By our accounting, about half of the South Atlantic's 14-percentage-point advantage in employment loss can be attributed to its higher trend employment growth. Industry composition had a negligible impact in the South Atlantic during this period. By contrast, industry composition played a significant role in the severity of the contraction in the Mountain division, adding about 13 percentage points to the region's employment loss relative to the national average. Adverse regional trend and cycle terms together account for another nine percentage points of the employment reduction in the Mountain states.

\footnotetext{
22 These industry effects resemble Marimon and Zilibotti's (" Actual' Versus 'Virtual' Employment") "virtual region," but here we present separate estimates of the trend and cycle effects of industry composition.

${ }^{29}$ It should be noted that the estimated industry trend effects for each region change somewhat between the 1929 to 1933 and 1933 to 1937 periods, even though the same trend coefficients are being used. The reason is the shift in industry employment shares between 1929 and 1933, which alters the weights used in the calculations.
} 
Industry composition contributed substantially to the better-than-average employment changes during the contraction in the West North Central and New England divisions. In both cases, the industry cycle effect predominates-that is, employment in both regions tended to be concentrated in nondurable goods producing industries in which employment movements were relatively less volatile. ${ }^{30}$ In these regions the industry effect offsets substantial negative contributions from the regional trends.

Employment losses in the East South Central region were quite severe between 1929 and 1933, although, as noted previously, our sample considerably overstates the employment change relative to the figures for manufacturing as a whole. In our sample, at least, the weak performance of the East South Central was a function of a strong negative cyclical shock to the region as a whole and an especially negative industry composition effect.

The adverse cyclical impact of industry composition in the East South Central, Pacific, and Mountain divisions can be traced to the heavy concentration of industrial employment in the lumber products industry in these regions. Table 8 shows the composition of industry employment in our sample in 1929. Lumber employed over 40 percent of the workers in our sample in each of these three divisions. Lumber, furthermore, suffered the largest cyclical shock of any industry in our sample during the 1929 to 1931 downturn (see the coefficients in Table 5). In other words, the dependence of these regional economies on demand from the construction industry left them vulnerable to the collapse of construction during the Depression. The importance of the automobile industry in the East North Central region had a similar impact on that division, as employment in motor vehicles and parts production suffered a large negative shock between 1929 and 1933.

Regions that did relatively poorly during the contraction tended to bounce back during the 1933 to 1937 recovery period. Examining the middle panel of Table 7, New England stands out as the weakest performer during the recovery. That region's dependence on cotton goods and boots and shoes, which dampened employment losses during the contraction, resulted in a large negative contribution of industry structure during the recovery (less volatile industries had less recovering to do). Adverse region-specific trend and cycle terms added to New England's weaker recovery in our sample.

Examining the entire 1929 to 1937 period in the bottom panel of Table 7, we find that both region-specific and industry composition effects help explain the regional variation in employment growth over the course of the Depression. In each of the southern divisions, for example, the effects of industry composition were quite negative. The two most important southern

${ }^{30}$ Among our sample industries cotton goods and boots and shoes accounted for close to 60 percent of employment in New England, and boots and shoes, bread, and meat packing accounted for close to 55 percent of employment in the West North Central (see Table 8). 
TABLE 8

INDUSTRIAL COMPOSITION OF SAMPLE EMPLOYMENT BY REGION, 1929 (percentages)

\begin{tabular}{lrrrrrrrrr}
\hline & SA & ESC & WSC & Pac & Mt & WNC & ENC & NE & MA \\
\hline Boots & 0.48 & 3.07 & 0.14 & 0.30 & 0.00 & 16.68 & 3.94 & 24.51 & 6.54 \\
Bread & 2.69 & 4.56 & 7.64 & 6.21 & 10.02 & 12.76 & 4.88 & 5.13 & 8.90 \\
Canning & 2.54 & 1.72 & 2.02 & 14.30 & 8.80 & 3.27 & 1.94 & 0.55 & 2.19 \\
Chemicals & 1.21 & 0.92 & 0.45 & 0.90 & 0.15 & 0.61 & 1.43 & 1.12 & 3.99 \\
Cigars, Cigarettes & 7.07 & 2.41 & 0.00 & 0.01 & 0.39 & 0.81 & 1.46 & 0.61 & 5.86 \\
Confectionery & 0.97 & 1.10 & 1.29 & 1.58 & 3.32 & 3.31 & 1.82 & 2.55 & 2.48 \\
Cotton Goods & 48.89 & 7.48 & 4.99 & 0.46 & 0.00 & 0.00 & 0.22 & 36.08 & 6.17 \\
Furniture & 5.90 & 5.13 & 3.01 & 4.63 & 0.56 & 4.83 & 8.14 & 3.77 & 5.39 \\
Glass & 2.72 & 0.00 & 0.89 & 0.61 & 0.00 & 0.00 & 2.11 & 0.00 & 3.47 \\
Iron & 2.76 & 3.80 & 0.00 & 3.01 & 0.00 & 2.15 & 15.59 & 0.00 & 24.25 \\
Lumber & 17.84 & 51.04 & 40.64 & 45.75 & 52.81 & 5.58 & 3.21 & 2.81 & 4.30 \\
Mea Packing & 0.64 & 1.26 & 3.77 & 2.30 & 6.27 & 24.06 & 4.48 & 0.88 & 2.09 \\
M:y perts & 0.12 & 2.35 & 1.00 & 0.99 & 0.20 & 3.24 & 16.38 & 1.34 & 4.61 \\
Motor Vehicles & 0.00 & 0.00 & 0.00 & 2.16 & 0.00 & 3.86 & 16.86 & 0.00 & 3.21 \\
Nonferrous Metals & 0.42 & 0.17 & 0.14 & 0.50 & 0.32 & 0.75 & 2.11 & 7.49 & 3.06 \\
Paper & 1.05 & 1.09 & 0.00 & 2.24 & 0.00 & 1.20 & 3.57 & 8.06 & 3.31 \\
Petroleum Refining & 0.34 & 5.09 & 23.95 & 3.23 & 5.47 & 1.97 & 0.65 & 0.33 & 2.45 \\
Planing-Mill Prods & 2.57 & 5.52 & 3.78 & 4.85 & 2.41 & 5.40 & 2.20 & 1.54 & 2.22 \\
Printing, Newspaper & 1.80 & 3.31 & 6.29 & 3.86 & 9.27 & 9.40 & 3.22 & 3.22 & 4.99 \\
Rubber tires, tubes & 0.00 & 0.00 & 0.00 & 2.12 & 0.00 & 0.12 & 5.82 & 0.00 & 0.49 \\
\hline
\end{tabular}

Note: Each column adds to 100 percent.

industries, lumber and cotton goods, both exhibit lower than average trend growth over our sample period. Only because of strong regional trends in employment growth were the South Atlantic and West South Central divisions able to experience above-average employment growth during this period.

By contrast, the regional trend in New England employment accounts for most of that division's very weak employment growth over the period. In the Mountain division, both regional and industry trends contributed to slow employment growth.

In the economy's industrial core (Middle Atlantic and East North Central divisions), industry trends made a strong positive contribution to employment growth rates. In the Middle Atlantic, this positive effect was offset almost completely by a relatively slow regional trend in employment growth. Comparing the second and final columns of the table, however, it is clear that our model does not, on balance, account for the difference in growth rates between the Middle Atlantic and East North Central over this period.

\section{Implications for Understanding the Depression}

Our analysis of regional variation in employment growth sheds light on several issues. First, regional variations in the trend of employment growth 
were at least as important as regional variations in the cyclical severity of the Depression downturn, once we control for industry composition. In particular, the milder contraction in the South Atlantic was largely a function of the greater trend growth rate of manufacturing employment there. These regional trends may be seen as part of the process of convergence in the sectoral structure of employment across U.S. regions during the twentieth century. ${ }^{31}$ Overall employment growth in manufacturing was most rapid in the South and the Pacific, slowest in the Northeast (see Table 6).

Second, the pattern of region-specific cyclical effects defies any simple generalizations about the sources of regional vulnerability to the contraction, and may call into question some widely cited hypotheses about the Depression. As we have noted, for example, the major waves of bank failures were often rural in origin and, at least until the 1933 panic, tended to occur at a much higher rate in the nation's more rural areas: the East and West North Central, South Atlantic, and East South Central divisions in particular. ${ }^{32}$ If disruption of local financial markets played an important role in propagating the Depression, this disruption might be expected to have spilled over to the manufacturing sector in these divisions. Yet by our estimates, these divisions show no consistent tendency toward a larger negative cyclical shock, controlling for industry composition. Of course, the fact that bank failures in agricultural areas-which tend to drive regional variations in bank failure rates before 1933 - did not have a significant spillover effect on manufacturing does not preclude an important role for bank failures and financial market disruptions within industrial areas.

A better place to look for an explanation of the collapse of manufacturing employment in certain regions would be the dependence of some regional economies on demand from the building industries. Those areas of the country may have suffered not only directly from employment losses in the lumber and wood processing industries, but from spillover effects on demand for locally produced goods, such as bread or newspapers. ${ }^{33}$

Third, variation across industries in the severity of the cyclical contraction played a large role in the 1929 to 1933 downturn, but over the course of the

\footnotetext{
${ }^{31}$ See Barro and Sala-i-Martin ("Convergence," pp. 382-92) for evidence on long-run trends in state per capita income. This convergence is presumably the result of adjustment from an initial disequilibrium position. Wright (Old South) attributes low wages in the South to the combination of weak international demand for cotton in the post-Civil War era and the lack of significant outmigration to the North until after World War I. More generally, patterns of regional comparative advantage are subject to recurrent shocks arising from the evolution of technology and market structures. On the reasons for New England's declining employment in this period, see Rosenbloom, "Challenges."

${ }^{32}$ Chandler, America's Greatest Depression, pp. 83-84.

${ }^{33}$ The causes and consequences of the collapse of the construction sector during the Depression are discussed in Field, "Uncontrolled Land Development." Here we emphasize not the direct effects of declining construction activity on local economies but the impact on manufacturing through the derived demand for inputs.
} 
decade broader industry growth trends made the largest contribution to regional variation in employment growth. Not surprisingly, the cyclical shock to employment was greater for industries dependent on the construction sector, and for producers of durable goods such as automobiles, iron, and furniture. Our analysis cannot distinguish between different sources of the volatility of these industries, such as differences in the income elasticity of demand, the impact of uncertainty, or the effects of market saturation.

\section{The Role of Hours of Work}

Although the movement of employment is of intrinsic interest, variations in employment may not accurately characterize variations in total labor input during the Depression, because average weekly working hours fell dramatically in many industries. ${ }^{34}$ When workers care about both wages and hours of work, hours reductions can have interesting, if ambiguous, implications for equilibrium real wages during a contraction. ${ }^{35}$ In some industries or regions, relatively small employment adjustments may have been accompanied by relatively large hours reductions. In such cases work sharing would have mitigated the employment effects of the demand shock. Changes in the incidence of shift work might also have influenced the number of hours per worker. For these reasons it would be desirable to estimate our model for total working hours, or separately for employment and average hours per worker.

Unfortunately, the Census of Manufactures did not collect data on working hours until 1933. The hours data used by Bernanke, which were collected by the National Industrial Conference Board (NICB), are aggregated to the national level. ${ }^{36}$ For the 11 industries in our sample that overlap with the NICB industries, we can compare the percentage reduction in hours with the percentage reduction in employment using a scatter diagram (Figure 4).

Although employment and hours reductions tended to be correlated across industries (the correlation is about 0.4 ), there was considerable variation in the relative importance of hours reductions. Hours reductions were particularly important in the iron and steel industry. Conversely, employment cuts account for the lion's share of total work-hour reductions in automobiles and lumber. Whereas the percentage employment loss in the lumber industry was about twice that in the iron and steel industry, the magnitudes of the reductions in total worker-hours were actually much more similar. ${ }^{37}$

${ }^{34}$ Bernanke and Powell, "Cyclical Behavior."

${ }^{35}$ Bernanke, "Employment."

${ }^{36}$ Ibid.

${ }^{37}$ The small number of industries represented in Figure 4 makes the correlation very sensitive to outliers. For example, if we exclude the two industries with unusually large employment reductions (automobiles and lumber), the correlation between hours and employment adjustments rises to about 0.6 . 


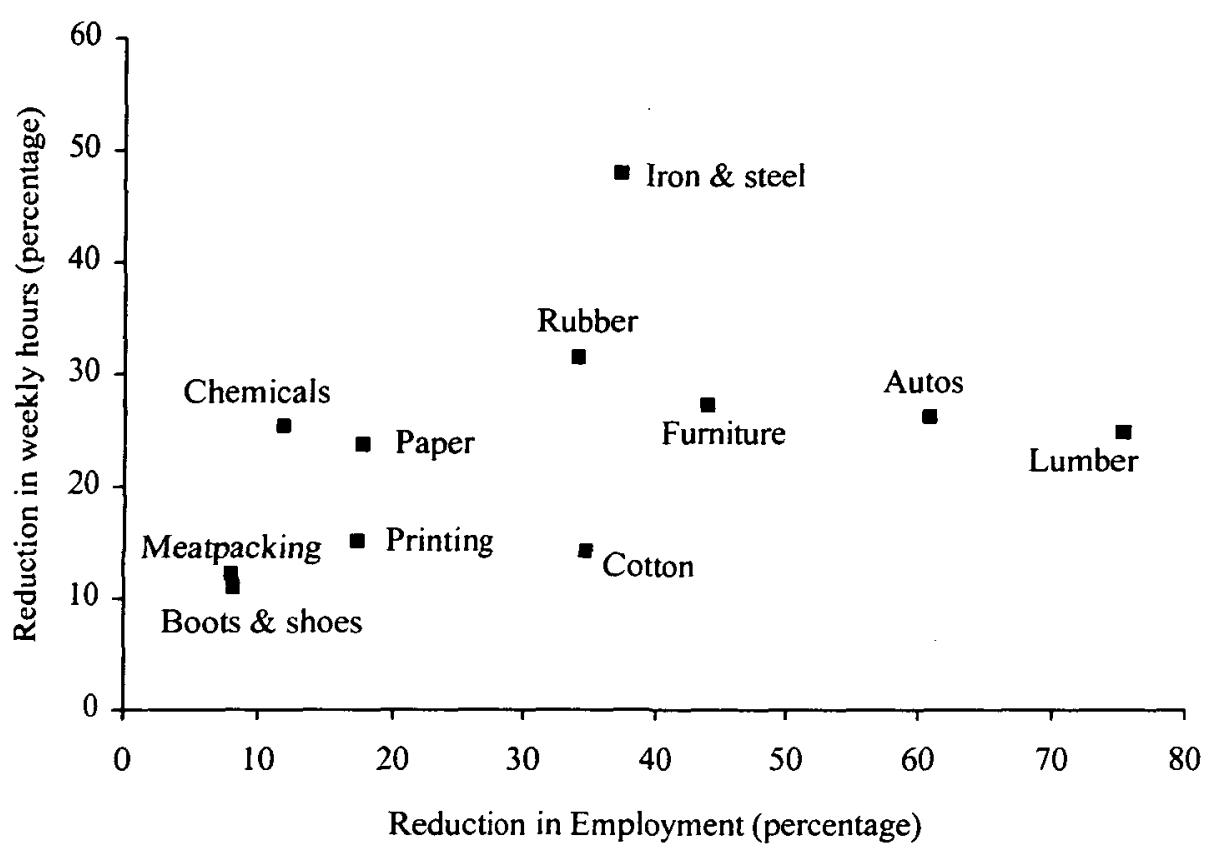

FIGURE 4

SCATTER OF HOURS VERSUS EMPLOYMENT REDUCTIONS, NICB INDUSTRIES, 1929-1933

Note: Proportional changes calculated as the change in natural log of employment. Source: Beney, Wages, various tables.

Some fragmentary evidence on hours of work disaggregated by industry and region is available in various Bureau of Labor Statistics reports on wages and hours, as well as the Census reports on "Man-Hour Statistics," which begin in 1933. These sources can provide some insights into movements in weekly hours in two industries that were especially significant in parts of the South: the cotton goods and lumber industries. Data for the period from 1928 to 1933 are summarized in Table 9.

A deficiency of the hours statistics for cotton is that the 1928 and 1930 numbers (from BLS reports) refer to scheduled full-time hours, whereas the 1933 figures (from the Census) are for actual hours. By 1930 the contraction had almost certainly resulted in shortened actual hours; furthermore, the depressed condition of the New England textile industry in the late 1920s may imply that actual hours there were already considerably below the reported "full-time" hours by 1928 . These caveats in mind, the table does suggest that the percentage reduction in working hours between 1930 and early 1933 was greater in the South Atlantic branch of the industry. Within the South Atlantic, a dramatic additional reduction in average actual hours 
TABLE 9

AVERAGE WEEKLY HOURS OF WORK IN THE COTTON AND LUMBER MANUFACTURING INDUSTRIES, 1928-1933

\begin{tabular}{|c|c|c|c|c|c|}
\hline Cotton & $\begin{array}{c}\text { New } \\
\text { England }^{1}\end{array}$ & $\begin{array}{c}\text { South } \\
\text { Atlantic }^{2}\end{array}$ & & & \\
\hline \multicolumn{6}{|l|}{ Weekly hours } \\
\hline Full-time, 1928 & 47.8 & 55.6 & & & \\
\hline Full-time, 1930 & 47.5 & 55.3 & & & \\
\hline Actual, January 1933 & 39.7 & 43.3 & & & \\
\hline Actual, November 1933 & 36.2 & 34.5 & & & \\
\hline Actual, Average 1933 & 39.4 & 40.0 & & & \\
\hline \multicolumn{6}{|l|}{ Changes (percentages) } \\
\hline $1928-1930$ & -0.7 & -0.6 & & & \\
\hline 1930-January 1933 & -17.8 & -24.5 & & & \\
\hline January 1933-November 1933 & -9.4 & -22.8 & & & \\
\hline 1930-Average. 1933 & -18.6 & -32.5 & & & \\
\hline Lumber & $\begin{array}{l}\text { East South } \\
\text { Central }\end{array}$ & Mountain $^{3}$ & Pacific & $\begin{array}{c}\text { South } \\
\text { Atlantic }^{4}\end{array}$ & $\begin{array}{l}\text { West South } \\
\text { Central }^{5}\end{array}$ \\
\hline \multicolumn{6}{|l|}{$\overline{\text { Weekly hours (actual) }}$} \\
\hline 1928 & 52.4 & 44.8 & 48.5 & 54.4 & 51.3 \\
\hline 1930 & 46.6 & 46.3 & 46.3 & 50.5 & 49.5 \\
\hline 1932 & 45.7 & 35.6 & 37.4 & 43.2 & 36.9 \\
\hline \multicolumn{6}{|l|}{ Changes (percentages) } \\
\hline $1928-1930$ & -11.7 & 3.5 & -4.6 & -7.4 & -3.6 \\
\hline $1930-1932$ & -1.8 & -26.3 & -21.4 & -15.6 & -29.5 \\
\hline $1928-1932$ & -13.5 & -22.9 & -26.0 & -23.0 & -33.1 \\
\hline
\end{tabular}

Notes: Regions correspond to census divisions except as noted.

1. Excludes Vermont in 1928 and 1930, includes it in 1933.

2. Georgia, North Carolina, South Carolina, and Virginia in 1928 and 1930; Maryland added in 1933.

3. Idaho, Montana.

4. Florida, Georgia, North Carolina, South Carolina, Virginia, West Virginia.

5. Arkansas, Louisiana, Texas.

Sources: U.S. Dept. of Labor, Bureau of Labor Statistics, Wages and Hours in Cotton-Goods Manufacturing, 1910-1930, BLS Bulletin No. 539, p. 9. U.S. Dept. of Commerce, Bureau of the Census, Census of Manufactures: 1933, Man-Hour Statistics for 32 Selected Industries, tables 2, 3. U.S. Dept. of Labor, Bureau of Labor Statistics, Wages and Hours in the Lumber Industry in the United States: 1928, BLS Bulletin No. 497, p. 36. U.S. Dept. of Labor, Bureau of Labor Statistics, Wages and Hours in the Lumber Industry in the United States: 1932, BLS Bulletin No. 586, p. 6.

occurred during 1933, coinciding with the implementation of the NRA code of 40 hours in textiles. In fact, by November of 1933, average hours in both regions had fallen to well below 40 hours, raising the question of whether the NRA hours code was actually binding.

Our decompositions suggest that employment reductions in the lumber industry were probably a significant factor in the relatively poor performance of the East South Central and Mountain divisions during the early 1930s. Table 9 shows that as of 1932, hours reductions were smaller in the East South Central branch of the lumber industry than elsewhere, although the region may have experienced more substantial reductions during 1933 
TABLE 10

ANOVA FOR PANEL MODEL OF PRODUCT VALUE GROWTH RATE

\begin{tabular}{lrrrrrr}
\hline \multicolumn{1}{c}{ Source } & Partial SS & \multicolumn{1}{c}{ df } & \multicolumn{1}{c}{ MS } & \multicolumn{1}{c}{ F } & Prob $>$ F & \\
\hline Model & 617.92 & 250 & 2.472 & 11.90 & 0.000 & \\
Year & 231.16 & 8 & 28.895 & 139.17 & 0.000 & \\
Region & 4.56 & 8 & 0.570 & 2.75 & 0.005 & \\
Ind & 19.13 & 19 & 1.007 & 4.85 & 0.000 & \\
Year*region & 21.53 & 64 & 0.336 & 1.62 & 0.001 & \\
Year*ind & 161.39 & 151 & 1.069 & 5.15 & 0.000 &. \\
Residual & 926.62 & 4,463 & 0.208 & & & \\
Total & $1,544.54$ & 4,713 & 0.328 & & & 4,714 \\
$N$ & & & & & & 0.4001 \\
$R$-squared & & & & & & 0.45566 \\
Root MSE & & & & & & 0.3665 \\
Adjusted & & & & & & \\
$\quad R$-squared & & & & & & \\
\hline
\end{tabular}

Notes: ANOVA estimate using 20-industry sample (see the text).

when the NRA code set weekly hours in lumber at 40 . On balance, the evidence on hours in the lumber industry suggests that if we could examine the reduction in total worker-hours, the contraction in the lumbering regions (especially the East South Central) would not look quite as severe as it does in terms of employment alone, as compared with other parts of the country.

The fragmentary evidence on hours summarized here indicates that there may have been significant regional differences in hours adjustments, both because of differences in industry composition and because of regional differences within industries. Consequently, our results for employment variation must be interpreted with care: they are not necessarily indicative of variations in total labor input, as measured by total worker hours. To the extent that regional differences in employment variations were offset by shifts in weekly hours, the question becomes why the margins of adjustment differed from one part of the country to another.

\section{RESULTS: PRODUCT VALUE}

The Census of Manufactures collected data not only on employment but also on the annual value of production and materials costs. Panel regression results for growth rates of nominal product value are presented in Tables 10 and 11, which are analogous to Tables 4 and 5 for employment growth. The analysis of variance, presented in Table 10, indicates that all the groups of dummy variables as well as their interactions are significant, with the year and year-by-industry effects again accounting for the bulk of the explained variation.

Interpretation of the results for nominal product value is hampered by the fact that movements in product value reflect the joint influence of price and 


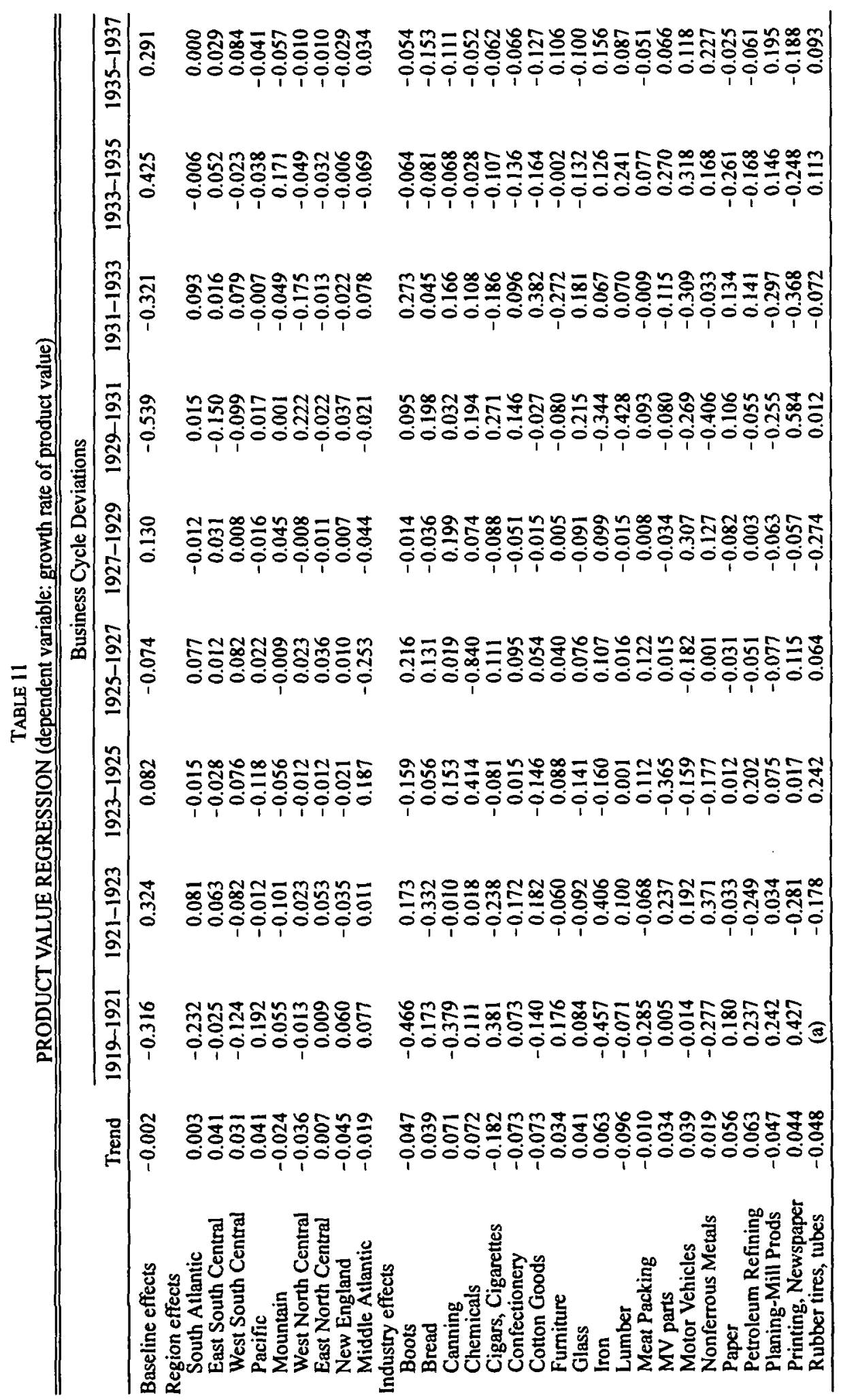


TABLE 11-continued

(a) Coefficient could not be estimated because of missing data.

Notes: Estimated OLS coefficients from panel regression model (see the text).

quantity changes. Sorting these effects out would require price indices disaggregated to the region and industry level, which to our knowledge are not available. A comparison of the coefficients in Tables 5 and 11 reveals similarities as well as differences between the behaviors of employment and product value. The patterns of region and industry time trends are generally similar, with the notable exception that the time trend in the South Atlantic is considerably weaker for product value than it is for employment. ${ }^{38}$

The business cycle deviations for product value during the Depression years are also qualitatively similar to those for employment. Among the industries, lumber and planing-mill products experienced substantial negative deviations during the 1929 to 1933 period, as did such durables industries as furniture, iron, and motor vehicles. The regional patterns of cyclical deviations are also similar to those for employment, with the South Atlantic again the exception: there, the region-specific cyclical component is much larger for product value than for employment during the 1931 to $1933 \mathrm{pe}-$ riod. In sum, the results for product value appear to be largely consistent with those for employment, with the exception of somewhat anomalous results for the South Atlantic division.

\section{RESULTS: TWO MEASURES OF LABOR COST}

The seemingly perverse upward movement of real wages during the first half of the Depression has been noted by a number of authors, and wage stickiness is often named as a likely suspect in creating the high unemployment rates of the 1930s. ${ }^{39}$ Wright argues that New Deal wage policies had a particularly strong effect in the South, where minimum wages were binding for a large percentage of workers and had adverse employment effects. ${ }^{40}$ Movements in labor costs may also have affected trend employment growth across regions. In our analysis of employment growth (see Table 5), we find significantly positive trend employment growth in all three southern divisions, which helped moderate the adverse effects of the Depression in the South. Was employment growth in the South associated with regional differences in wage trends that were making the South relatively attractive to employers?

\footnotetext{
${ }^{38}$ The weaker trend of product value in the South Atlantic would be consistent with greater reductions in working hours there, which would lead to lower output levels, given employment.

${ }^{39}$ On this issue see Margo, "Employment"; Dighe, "Wage Rigidity"; and sources cited therein.

${ }^{40}$ Wright, Old South, pp. 216-25.
} 
To investigate regional and industrial movements in labor costs, we derive two measures from our Census data. The first is simply the nominal average annual earnings of wage earners, which we calculate by dividing the annual wages by average annual employment. Because we do not have disaggregated measures of product prices, we cannot deflate the average annual earnings to a real product wage. Furthermore, the annual earnings figures do not reflect changes in annual hours worked.

The second measure of labor costs is the ratio of total wage payments (wage bill) to value added (product value minus materials costs), or the wage share of value added. This measure corresponds to the "adjusted real wage" used by Richard Vedder and Lowell Gallaway, and is also equivalent to the ratio of the real hourly product wage to average labor productivity per worker hour. ${ }^{41}$ As a measure of real labor costs, the wage share has two advantages: first, it is proportional to the hourly product wage and is not directly sensitive to hours per worker; and second, it is deflated by the product price. It will, however, vary inversely with changes in labor productivity.

The panel results for the growth rate of each measure of labor costs are summarized in the ANOVA tables presented in Table 12: the upper panel uses the growth rate of average annual earnings as the dependent variable, the lower panel uses the growth rate of the wage share. ${ }^{42}$ For neither measure are the regional dummy variables significant. In other words, these results provide no evidence of regional differences in trend growth of labor costs during this period.

Nominal annual earnings did exhibit statistically significant regional differences in the cyclical component, and the regression coefficients (not reported here) do provide some evidence of faster earnings growth in much of the South during the NRA period, 1933 through 1935. During the NRA years, the national average of nominal earnings in our sample rose 16.1 percentage points faster than trend; in the South Atlantic, earnings growth was about 2.4 percentage points greater than that; and in the East South Central, it was 1.3 percentage points greater. On the other hand, the industry effects for the same period show falling earnings in some of the dominant low-wage southern industries, including cigars and cigarettes and cotton goods. ${ }^{43}$

\footnotetext{
${ }^{41}$ Vedder and Gallaway, Out of Work. To see this, note that value added is $P q-R a q$, where $P$ is the output price, $q$ is the quantity produced, $R$ is an index of materials prices, and $\alpha$ is the amount of materials per unit of output. The wage bill is $W E H$, where $W$ is the hourly wage, $E$ is employment, and $H$ is average annual hours per worker. Then the wage share of value added is $W E H /(P q-R \alpha q)=$ $W /(P-R \alpha) * 1 /(q / E H)=w / \lambda$, where $w$ is the real hourly product wage (deflated by value added per unit) and $\lambda$ is the average productivity of labor.

${ }^{42}$ Full tables of the estimated regression coefficients are available in an appendix from the authors.

${ }^{43}$ This latter effect may reflect the southern differentials written into some NRA codes, which allowed southern manufacturers to play lower wages in some circumstances.
} 
TABLE 12

ANOVA FOR PANEL MODELS OF GROWTH RATE IN LABOR COSTS

\begin{tabular}{|c|c|c|c|c|c|c|}
\hline Source & Partial SS & $\mathrm{df}$ & MS & $\mathbf{F}$ & Prob $>F$ & \\
\hline \multicolumn{7}{|c|}{ Panel A: Dependent Variable: Growth Rate of Nominal Average Annual Earnings } \\
\hline Model & 98.37 & 250 & 0.393 & 10.07 & 0.000 & \\
\hline Year & 30.33 & 8 & 3.791 & 97.02 & 0.000 & \\
\hline Region & 0.10 & 8 & 0.013 & 0.33 & 0.954 & \\
\hline Ind & 1.53 & 19 & 0.080 & 2.06 & 0.005 & \\
\hline Year*region & 3.78 & 64 & 0.059 & 1.51 & 0.006 & \\
\hline Year*ind & 32.53 & 151 & 0.215 & 5.51 & 0.000 & \\
\hline Residual & 174.43 & 4,464 & 0.039 & & & \\
\hline Total & 272.79 & 4,714 & 0.058 & & & \\
\hline$N$ & & & & & & 4,715 \\
\hline$R$-squared & & & & & & 0.361 \\
\hline Root MSE & & & & & & 0.19767 \\
\hline Adjusted & & & & & & 0.325 \\
\hline
\end{tabular}

Panel B: Dependent Variable: Growth Rate of Wage Share of Value Added

\begin{tabular}{lrrrrrl} 
Model & 176.49 & 249 & 0.709 & 3.49 & 0.000 & \\
year & 27.69 & 8 & 3.462 & 17.07 & 0.000 & \\
region & 0.35 & 8 & 0.044 & 0.22 & 0.988 & \\
ind & 0.91 & 19 & 0.048 & 0.24 & 1.000 & \\
year*region & 12.04 & 64 & 0.188 & 0.93 & 0.641 & \\
year*ind & 125.96 & 150 & 0.840 & 4.14 & 0.000 & \\
Residual & 871.05 & 4,294 & 0.203 & & & \\
Total & 1047.54 & 4,543 & 0.231 & & & 4,544 \\
$N$ & & & & & & 0.1685 \\
$R$-squared & & & & & 0.45039 \\
Root MSE & & & & & 0.120 \\
Adjusted & & & & & \\
$\quad R$-squared & & & & & \\
\hline
\end{tabular}

Notes: ANOVA estimates using 20-industry sample. See the text for definitions of the dependent variables.

For the wage share variable, only the year effects and year-by-industry interactions are significant (see the lower panel of Table 12). By this measure of labor costs, there are no significant region effects in either the trend or cyclical components. These results appear to be at odds with Wright's argument that New Deal policies raised real wages relatively more in the South than elsewhere. Only if regional differences in the movement of real product wages were masked by offsetting regional differences in the path of average labor productivity would our results be consistent with this hypothesis.

\section{CONCLUSIONS}

We have shown that regional variation in the severity of the Great Depression in manufacturing can be attributed largely to two factors: regional dif- 
ferences in trend employment growth, and regional differences in industrial composition. Put somewhat differently, the severity of the Depression downturn did not actually differ dramatically across regions, once we account for trends and industry structure. Regional manufacturing sectors that were more concentrated in the production of goods with highly volatile demand, such as durables and inputs to construction, were relatively hard hit. Regions that were experiencing higher trend growth rates of employment experienced a somewhat milder contraction.

Overall, then, the Depression's impact was truly national in scope, perhaps because the principal demand shocks were common to all regions (for example, due to Federal Reserve policy), or because the impact of the shocks spread through national product markets to affect all regions. We find little evidence that regional variation in the severity of bank failure waves had region-specific effects on local economies; nor do we find systematic evidence that New Deal policies raised wage costs or reduced employment more in the low-wage South than elsewhere. Future attempts to explain the depth and duration of the Great Depression using disaggregated data would do well to focus on causes that varied across industries, where we have found the most substantial differences in the impact of the contraction.

\section{REFERENCES}

Alexander, Barbara J. "Failed Cooperation in Heterogeneous Industries Under the National Recovery Administration." this JOURNAL 57, no. 2 (1997): 322-44.

Barro, Robert J., and Xavier Sala-i-Martin. "Convergence Across States and Regions." Brookings Papers on Economic Activity 1 (1991): 107-82.

Beney, M. Ada. Wages, Hours, and Employment in the United States, 1914-1936. New York, National Industrial Conference Board, 1936.

Bernanke, Ben S. "Nonmonetary Effects of the Financial Crisis in the Propagation of the Great Depression." American Economic Review 73, no. 3 (1983): 257-76.

. "Employment, Hours, and Earnings in the Depression: An Analysis of Eight Manufacturing Industries." American Economic Review 76, no. 1 (1986): 82-109.

Bernanke, Ben S., and James L. Powell. "The Cyclical Behavior of Industrial Labor Markets: A Comparison of the Prewar and Postwar Eras." In The American Business Cycle: Continuity and Change, edited by Robert J. Gordon, 583-637. Chicago: University of Chicago Press, 1986.

Bernstein, Michael A. The Great Depression: Delayed Recovery and Economic Change in America, 1929-1939. New York: Cambridge University Press, 1987.

Blanchard, Olivier J., and Lawrence F. Katz. "Regional Evolutions." Brookings Papers on Economic Activity 1 (1992): 1-61.

Borts, George H. "Regional Cycles of Manufacturing Employment in the United States, 1914-1953." Journal of the American Statistical Association 55, no. 289 (1960): 151-211.

Calomiris, Charles W. "Financial Factors in The Great Depression." Journal of Economic Perspectives 7, no. 2 (1993): 61-85.

Chandler, Lester V. America's Greatest Depression, 1929-1941. New York: Harper and Row, 1970. 
Clark, Todd. "Business Cycle Fluctuations in U.S. Regions and Industries: The Roles of National, Region-Specific, and Industry-Specific Shocks." Federal Reserve Bank of Kansas City Research Working Paper 92-05, November 1992.

Dighe, Ranjit S. "Wage Rigidity in the Great Depression: Truth? Consequences?" Research in Economic History 17 (1997): 85-134.

Field, Alexander J. "Asset Exchanges and the Transactions Demand for Money, 19191929." American Economic Review 74, no. 1 (1984): 43-59.

"Uncontrolled Land Development and the Duration of the Depression in the United States." this JOURNAL 52, no. 4 (1992): 785-805.

Friedman, Milton, and Anna J. Schwartz. A Monetary History of the United States, 18671960. Princeton, NJ: Princeton University Press, 1963.

Ghosh, Atish R., and Holger C. Wolf. "Geographical and Sectoral Shocks in the U.S. Business Cycle." NBER Working Paper 6180, September 1997.

Hamilton, James. "Monetary Factors in the Great Depression." Journal of Monetary Economics 19, no. 2 (1987): 145-69.

Krepps, Matthew B. "Another Look at the Impact of the National Industrial Recovery Act on Cartel Formation and Maintenance Costs." Review of Economics and Statistics 79, no. 1 (1997): 151-54.

Margo, Robert A. "Employment and Unemployment in the 1930s." Journal of Economic Perspectives 7, no. 2 (1993): 41-59.

Marimon, Ramon, and Fabrizio Zilibotti. “'Actual' Versus 'Virtual' Employment in Europe: Is Spain Different?" Centre for Economic Policy Research (London) Discussion Paper No. 1427, July 1996.

Romer, Christina D. "The Great Crash and the Onset of the Great Depression." Quarterly Journal of Economics 105, no. 3 (1990): 597-624.

Rosenbloom, Joshua L. "The Challenges of Economic Maturity: New England, 18801940." In The Economic History of New England, edited by Peter Temin. Cambridge, MA: Harvard University Press, forthcoming 2000.

Samolyk, Katherine A. "Banking Conditions and Regional Economic Performance: Evidence of a Regional Credit Channel." Journal of Monetary Economics 34, no. 2 (1994): 259-78.

Schmitz, Mark, and Price V. Fishback. "The Distribution of Income in the Great Depression: Preliminary State Estimates." this JOURNAL 43, no. 1 (1983): 217-30.

Sherwood-Call, Carolyn. "Exploring the Relationships between National and Regional Fluctuations." Federal Reserve Bank of San Francisco Economic Review (Summer 1988).

Simon, Curtis J., and Clark Nardinelli. "Does Industrial Diversity Always Reduce Unemployment? Evidence from the Great Depression and After." Economic Inquiry 30, no. 2 (1992): 384-97.

Szostak, Rick. Technological Innovation and the Great Depression. Boulder, CO: Westview Press, 1995.

Temin, Peter. Did Monetary Forces Cause the Great Depression? New York: Norton, 1976.

. Lessons from the Great Depression. Cambridge, MA: MIT Press, 1989.

U.S. Department of Commerce, Bureau of the Census. Abstract of the Censzis of Manufactures, 1919. Washington, DC: GPO, 1923.

U.S. Department of Commerce, Bureau of the Census. Censtus of Manufactures. Washington, DC: GPO, various years.

.Fifteenth Censtus of the United States: 1930, Unemployment. Vol. 1. Washington, DC: GPO, 1931.

. Fifteenth Census of the United States: 1929, Manufactures. Vol. 2. Washington, 
DC: GPO, 1933.

. Census of American Business: 1933, Retail Distribution. Vol. 1. Washington, DC: GPO, 1935.

. Sixteenth Census of the United States: 1940, Population. Vol. 3. Part 1. Washington, DC: GPO, 1943.

. Census of Business: 1940. Retail Trade: 1939. Part 1. Washington, DC: GPO, 1943.

U.S. Department of Labor, Bureau of Labor Statistics. Wages and Hours in the Lumber Industry in the United States: 1928. BLS Bulletin No. 497. Washington, DC: GPO, 1929. . Wages and Hours in Cotton-Goods Manufacturing, 1910-1930. BLS Bulletin No. 539. Washington, DC: GPO, 1931.

.Wages and Hours in the Lumber Industry in the United States, 1932. BLS Bulletin No. 586. Washington, DC: GPO, 1933.

Vedder, Richard, and Lowell Gallaway. Out of Work: Unemployment and Government in Twentieth-Century America. New York: Holmes and Meier, 1993.

Wallis, John J. "Employment in the Great Depression: New Data and Hypotheses." Explorations in Economic History 26, no. 1 (1989): 45-72.

Wicker, Elmus. The Banking Panics of the Great Depression. Cambridge: Cambridge University Press, 1996.

Wright, Gavin. "The Political Economy of New Deal Spending: An Econometric Analysis." Review of Economics and Statistics 56, no. 1 (1974): 30-38.

. Old South, New South. New York: Basic Books, 1986. 